JURNAL KACAPURI

JURNAL KEILMUAN TEKNIK SIPIL

Volume 3 Nomor 1 Edisi Juni 2020

\title{
KUALITAS WALKABILITY JALUR PEJALAN KAKI PADA KAWASAN BISNIS SIMPUR CENTER DAN SEKITAR
}

\author{
Goldie Melinda Wijayanti ${ }^{(1)}$ Anggi Agustina ${ }^{(2)}$ Rahayu Sulistyorini ${ }^{(3)}$ \\ (1) (2) (3) Institut Teknologi Sumatera \\ E-mail: goldie.wijayanti@pwk.itera.ac.id \\ E-mail: anggiagustina07@gmail.com \\ E-mail: rahayu@itera.ac.id
}

\begin{abstract}
ABSTRAK
Penggunaan lahan sebagai kawasan pusat bisnis $(C B D)$ merupakan salah satu ciri sebuah kawasan perkotaan. Salah satu infrastruktur perkotaan yang harus tersedia yaitu jalur pejalan kaki, karena adanya kegiatan perpindahan moda transportasi. Jalur pejalan kaki di Jl. Raden Intan adalah salah satu jalur pejalan kaki yang paling aktif di Kota Bandarlampung karena selain kegiatan perdagangan dan jasa juga dekat dengan Stasiun Tanjung Karang. Eksisting jalur pejalan kaki di di kawasan simpur center berdasarkan hasil analisis menggunakan parameter walkability dan teknik survai walkthrough didapatkan hasil skala penilaian dengan proporsi terbanyak yaitu jalur pejalan kaki buruk. Dari hasil pengamatan ada beberapa yang perlu ditingkatkan untuk mendukung walkability di kawasan perbelanjaan simpur center berfungsi sesuai peruntukan sebagai $C B D$ dan transit, seperti ketersediaan jalur pejalan kaki yang bebas hambatan, penyediaan fasilitas bagi pejalan kaki berkebutuhan khusus dan jalur pejalan kaki harus bersifat kontiyu.
\end{abstract}

Kata Kunci: Kota Bandarlampung, Kawasan CBD, Simpur Center, Walkability, Transportasi Non Motor

\section{ABSTRACT}

The use of the land as central business district (CBD) is one of the characteristics of an urban area. One of the urban infrastructure which must be available, namely the path of a pedestrian, due to the displacement mode of transportation. Pedestrian lane on Jl. Raden Intan is one of the pedestrian paths that are most active in the City of Bandarlampung because in addition to the activities of trade and services are also close to Tanjung Karang railway station. The existing pedestrian paths in the area of simpur center based on the results of the analysis using the parameters of the walkability and technique survey walkthrough the obtained results of the scale ratings with the highest proportion i.e. pedestrian path. From the results of observations there are some that need to be improved to support walkability in a shopping area of simpur center functioning as intended as the CBD and transit, such as the availability of pedestrian paths that are free of barriers, provision of facilities for pedestrians with special needs and pedestrian paths should be continued.

Keywords: Bandarlampung City, CBD Area, Simpur Center, Walkability, Non Motorized Transport 


\section{PENDAHULUAN}

\section{Latar Belakang}

Penggunaan lahan sebagai Central Business District (CBD) merupakan salah satu ciri sebuah kawasan perkotaan. Beberapa elemen penting pembentuk struktur kota yaitu bentuk kota, interaksi dalam kota dan mekanisme pengaturan penggunaan lahan dan pergerakan (Bourne, 1982). Menurut (Shirvani, 1985) terdapat beberapa sistem yang dapat mempengaruhi guna lahan yaitu sistem lingkungan yaitu lokasi sumber daya yang perlu dilindungi, seperti kawasan lindung dan kawasan budidaya; sistem pengembangan lahan yaitu pengembangan lahan yang belum optimal seperti penggunaan fungsi perkantoran, area terbangun dan lahan pertanian; dan sistem kegiatan yaitu sistem yang mencerminkan macam-macam kegiatan yang berlangsung diatasnya, seperti permukiman, perdagangan dan jasa, pendidikan, industri dan sebagainya. Non-Motorized Transport (NMT) adalah elemen penting untuk mendorong tranportasi di perkotaan dan juga NMT merupakan aspek penting dalam menciptakan sistem transportasi yang nyaman, aman dan efisien serta terintegrasi antar moda transportasi (ITDP, 2016). Salah satu prasarana perkotaan yang harus tersedia dalam mendukung pergerakan NMT sebuah kota yaitu jalur pejalan kaki bagi pedestrian, karena adanya aktivitas perpindahan moda transportasi. Kawasan simpur center berada di pusat kota yaitu Jl. Raden Intan yang merupakan salah satu jalur pejalan kaki paling aktif di Kota Bandarlampung karena selain kegiatan perdagangan dan jasa juga dekat dengan Stasiun Tanjung Karang. Moda transportasi yang tersedia di Kawasan simpur center yaitu angkot, trans lampung, ojek online dan ojek konvensional. Kondisi terkini jalur pejalan kaki di kawasan bisnis simpur center mengalami beberapa masalah dan hambatan samping menyebabkan kemacetan lalu lintas. Hal ini menyebabkan pertimbangan terhadap kualitas walkability di kawasan bisnis simpur center dan sekitar.

\section{Rumusan Masalah}

Adanya permasalahan transportasi yaitu kemacetan dan rendahnya tingkat keamanan dan keselamatan pejalan kaki menjadikan perlunya rekomendasi penyediaan jalur pejalan kaki yang walkable. Sehingga muncul pertanyaan penelitian yaitu Bagaimana menyediakan jalur pejalan kaki yang walkable di kawasan bisnis simpur center.

\section{Tujuan dan Sasaran}

Tujuan dari penelitian ini adalah rekomendasi penyediaan jalur pejalan kaki berdasarkan tingkat walkability jalur pejalan kaki di kawasan bisnis simpur center. Sasaran yang harus dicapai yaitu:

a) Identifikasi pola penggunaan lahan di kawasan bisnis simpur center dan sekitar;

b) Identifikasi perilaku pergerakan pejalan kaki berdasarkan tujuan perjalanan;

c) Identifikasi tingkat walkability di kawasan bisnis simpur center dan sekitar;

d) Merumuskan rekomendasi penyediaan jalur pejalan kaki yang walkable di kawasan bisnis simpur center dan sekitar.

\section{Ruang Lingkup}

Ruang lingkup yang akan dibahas adalah ruang lingkup substansi dan wilayah. Ruang lingkup substansi adalah mengukur tingkat walkability jalur pejalan kaki dikawasan bisnis simpur center menggunakan teknik walkthrough serta rekomendasi arahan penyediaan jalur pejalan kaki berdasarkan parameter walkability. 


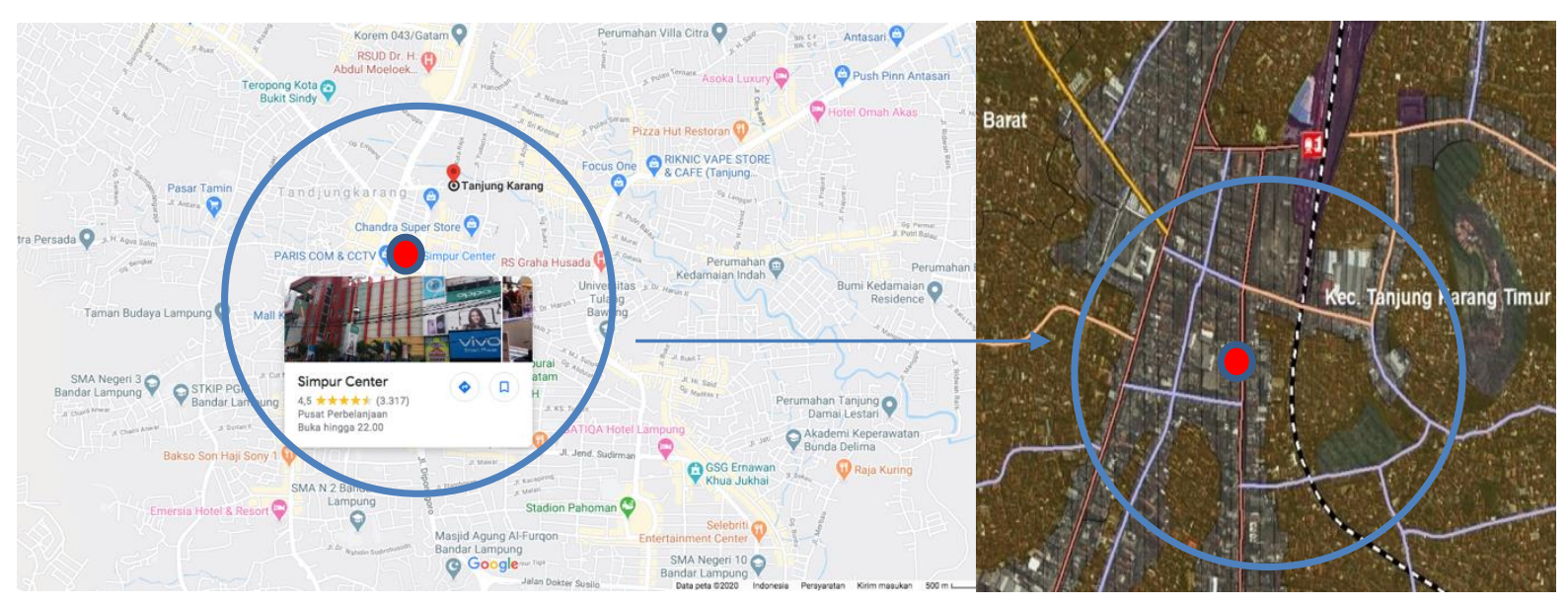

Gambar 1. Wilayah Studi Penelitian

Ruang linkup wilayah adalah radius 200 meter dari kawasan bisnis simpur center sampai Terminal KA Tanjung Karang. Wilayah studi penelitian berada di Jl. Raden Intan, yang merupakan kawasan bisnis di Kota Bandarlampung.

\section{METODE PENELITIAN}

Pendekatan penelitian yang akan digunakan dalam penelitian ini adalah deskriptif evaluatif, karena penelitian akan mengevaluasi kesesuaian kondisi eksisting dengan kriteria walkability index. Untuk mendapatkan gambaran kondisi eksisting, dilakukan survai lapangan oleh peneliti. Teknik survai yang digunakan adalah walkthrough, yang merupakan teknik pengkajian kualitas perkotaan yang dilakukan dengan berjalan ke area yang telah ditetapkan sebagai area observasi (Ministry for the Environment of New Zealand, 2006).

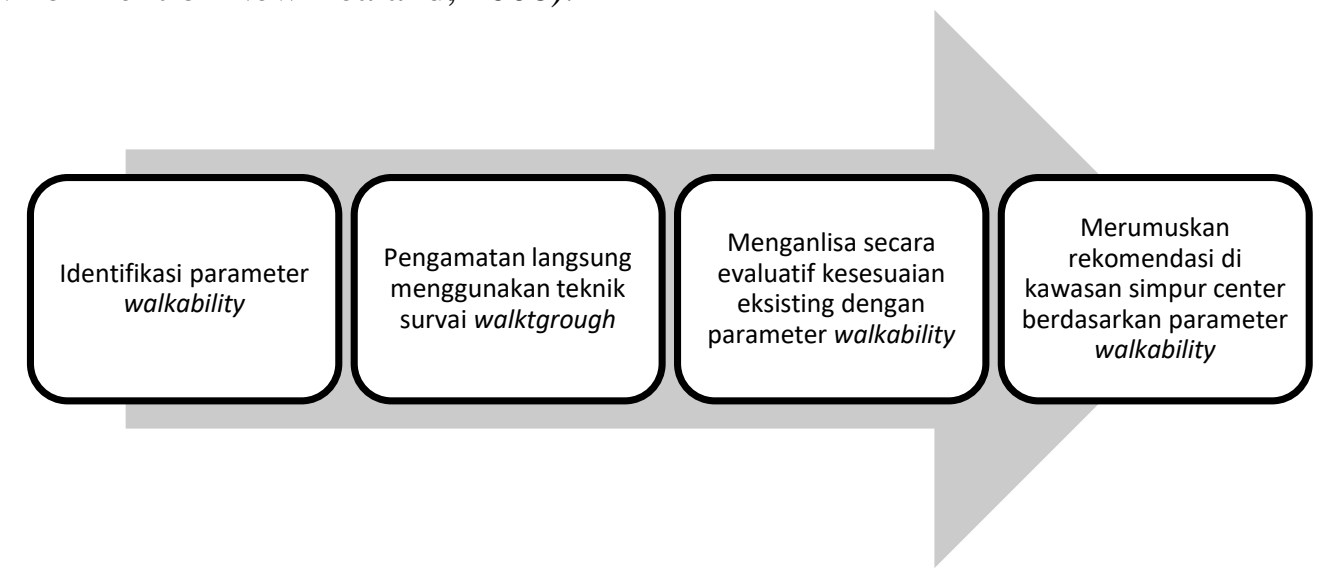

Gambar 2. Tahapan Proses Penelitian di Kawasan Bisnis Simpur Center

Teknik survai walkthrough dilakukan dengan pengamatan secara langsung oleh peneliti di lokasi penelitian dengan berjalan menyusuri Kawasan bisnis simpur center. Hasil yang didapatkan adalah kondisi eksisting terkait kualitas walkability kawasan bisnis simpur center. Data sekunder yang digunakan berupa undang-undang dan kebijakan terkait penyediaan jalur pejalan kaki perkotaan. Litman (2014) mengemukakan walkability memperhitungkan beberapa parameter, yakni kualitas fasilitas, konektivitas jalur, kondisi jalan, pola tata guna lahan, dukungan masyarakat, kenyamanan, serta rasa aman saat berjalan. Walkability dapat dievaluasi pada skala lokasi, ruas 
jalan, ataupun skala lingkungan. Penelitian oleh Leather et al. (2011) yang mengkaji walkability di beberapa negara di Asia, menggunakan parameter-parameter yang dimodifikasi dari GWI. Pada penelitian ini menggunakan parameter sperti pada Tabel 1. Parameter walkability oleh ADB yang akan digunakan untuk indikator mengenai kelayakan suatu kawasan bagi pedestrian dan meningkatkan kegiatan berjalan kaki dengan teknik survai walkthrough.

\section{Tabel 1. Paramater Walkability oleh ADB}

\begin{tabular}{|l|l|l|}
\hline \multicolumn{2}{|l|}{ Parameter } & Indikator \\
\hline $\mathbf{1}$ & $\begin{array}{l}\text { Konflik jalur pejalan kaki } \\
\text { dengan moda transportasi } \\
\text { lainnya }\end{array}$ & $\begin{array}{l}\text { Tingkat konflik antara pejalan kaki dan mode lain di jalan, } \\
\text { seperti sepeda, sepeda motor dan mobil. }\end{array}$ \\
\hline $\mathbf{2}$ & Ketersediaan jalur pejalan kaki & Kebutuhan, ketersediaan dan kondisi jalur berjalan. \\
\hline $\mathbf{3}$ & Ketersediaan penyeberangan & $\begin{array}{l}\text { Ketersediaan dan panjang penyeberangan untuk menjelaskan } \\
\text { apakah pejalan kaki cenderung menyebrang di jalan umum } \\
\text { ketika tidak ada penyeberangan atau ketika penyeberangan } \\
\text { terlalu jauh. }\end{array}$ \\
\hline $\mathbf{4}$ & Keselamatan penyeberangan & $\begin{array}{l}\text { Arus lalu lintas moda lainnya saat melintasi jalan, waktu yang } \\
\text { dihabiskan menunggu dan menyeberang jalan dan jumlah } \\
\text { waktu yang diberikan kepada pejalan kaki untuk } \\
\text { menyeberang persimpangan dengan sinyal. }\end{array}$ \\
\hline $\mathbf{5}$ & $\begin{array}{l}\text { Perilaku Pengendara Kendaraan } \\
\text { bermotor }\end{array}$ & $\begin{array}{l}\text { Perilaku pengendara terhadap pejalan kaki sebagai indikasi } \\
\text { jenis lingkungan pejalan kaki. }\end{array}$ \\
\hline $\mathbf{6}$ & $\begin{array}{l}\text { Amenities (kelengkapan } \\
\text { pendukung) }\end{array}$ & $\begin{array}{l}\text { Ketersediaan fasilitas pejalan kaki, seperti bangku, lampu } \\
\text { jalan, toilet umum, dan pohon-pohon, yang sangat } \\
\text { meningkatkan daya tarik dan kenyamanan lingkungan pejalan } \\
\text { kaki, dan juga daerah di sekitarnya. }\end{array}$ \\
\hline $\mathbf{7}$ & $\begin{array}{l}\text { Infrastruktur penunjang } \\
\text { kelompok penyandang cacat }\end{array}$ & $\begin{array}{l}\text { Ketersediaan, posisi dan pemeliharaan infrastruktur untuk } \\
\text { penyandang cacat. }\end{array}$ \\
\hline $\mathbf{8}$ & Kendala/ hambatan & $\begin{array}{l}\text { Adanya penghalang permanen dan sementara di jalur pejalan } \\
\text { kaki yang akan mengurangi lebar efektif jalur pejalan kaki } \\
\text { sehingga dapat menyebabkan ketidaknyamanan bagi pejalan } \\
\text { kaki. }\end{array}$ \\
\hline $\mathbf{9}$ & Keamanan dari kejahatan & Rasanang umum terhadap kejahatan di jalan. \\
\hline
\end{tabular}

Sumber: Leather et al. (2011) yang dimodifikasi.

Selanjutnya untuk melihat pola pergerakan pejalanan kaki dari tujuan berjalan adalah dengan penyebaran kuesioner online kepada masyarakat Kota Bandarlampung yang pernah menggunakan atau berjalan di jalur pejalan kaki di kawasan bisnis simpur center dan sekitarnya. Sampel yang diambil berjumlah 100 responden, dengan kriteria pernah melewati jalur pejalan kaki di wilayah studi. Penyebaran kuesioner secara online dilakukan karena keterbatasan berinteraksi dengan masyarakat karena anjuran social and physical distancing. 


\section{HASIL \& PEMBAHASAN}

\section{Pola Penggunaan Lahan di Kawasan Bisnsis Simpur Center dan Sekitar}

Penggunaan lahan di sekitar kawasan bisnis simpur center pada radius 200 meter dari jalur pejalan kaki adalah sebagai perdagangan dan jasa. Kawasan bisnis simpur center berada di jalan kolektor sekunder yang melayani angkutan pengumpulan atau pembagian dengan ciri-ciri perjalanan jarak sedang, kecepatan rata-rata sedang, dan jumlah jalan masuk dibatasi, dengan peranan pelayanan jasa distribusi untuk masyarakat di dalam kota.

Terdapat tiga titik kumpul/transit untuk pergantian moda yaitu pada halte bus disekitar kawasan bisnis simpur center. Sebaran titik kumpul/transit berada dekat dengan calon penumpang moda. Beberapa jenis moda yang mendukung kegiatan transit pejalan kaki seperti Kereta Api, Bus Trans Bandarlampung dan beberapa trayek angkutan. Trayek angkutan kota yang melewati kawasan bisnis simpur center, seperti trayek Tanjung Karang - Rajabasa, Tanjung Karang - Way Halim, Tanjung Karang - Kemiling, Tanjung Karang - Sam Ratulangi, Tanjung Karang - Sukarame, Tanjung Karang - Permata Biru, Tanjung Karang - Ir Sutami, Tanjung Karang - Teluk Betung, dan Sukaraja - Panjang.

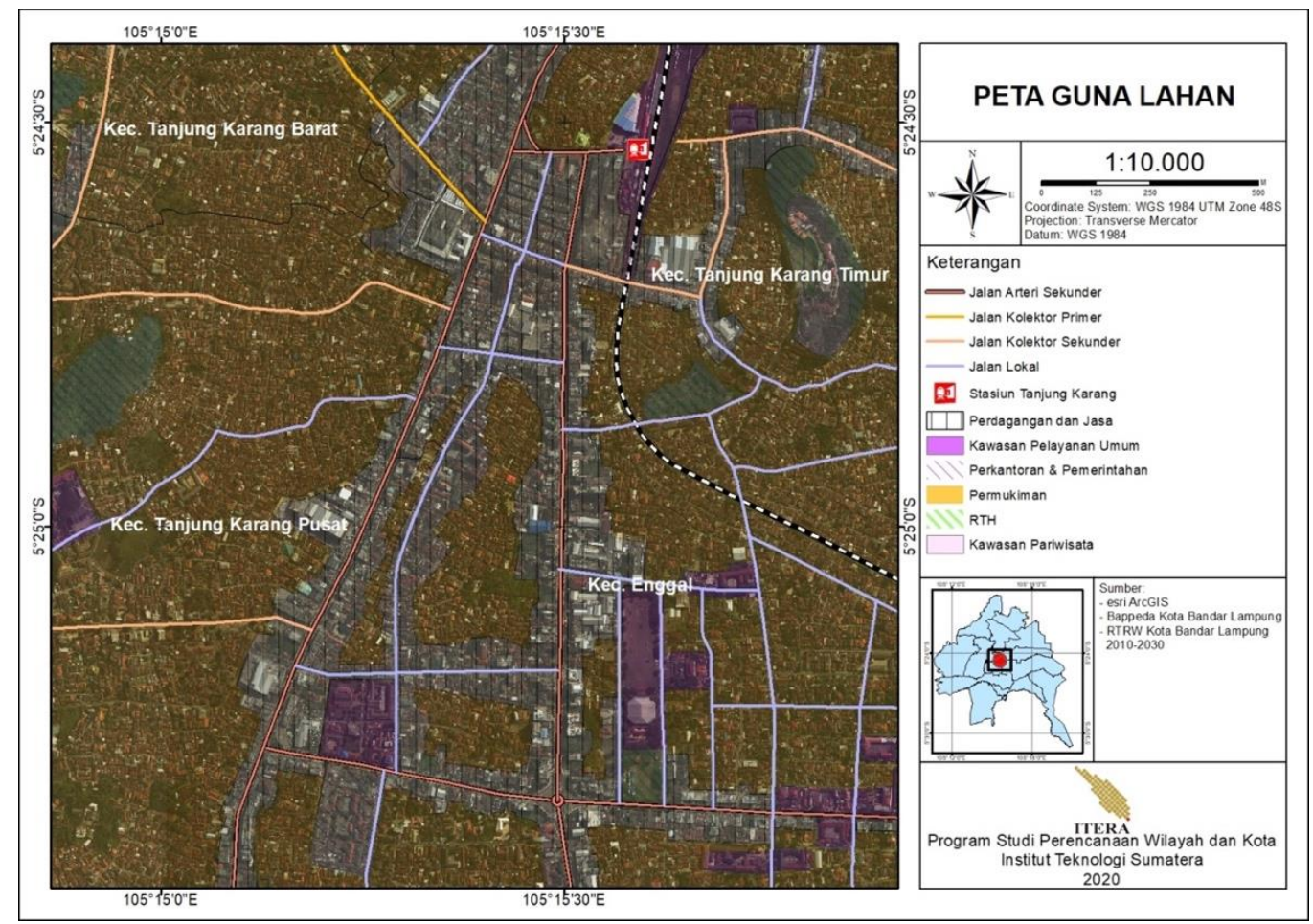

Gambar 4. Peta Guna Lahan di Kawasan Bisnis Simpur Center dan sekitarnya

Angkutan ini yang mendukung pejalan kaki melakukan pergerakan asal tujuan ke kawasan bisnis simpur center. Sehingga menjadi penting penyediaan jalur pejalan kaki sebagai sarana pendukung melakukan perpindahan moda. 


\section{Perilaku Pergerakan Pejalan Kaki Berdasarkan Tujuan Perjalanan}

Berdasarkan hasil kuesioner online yang ditujukan kepada pejalan kaki, tujuan perjalanan pejalan kaki di dominasi oleh pejalan kaki dengan tujuan berbelanja dan olahraga. Hal ini dapat dikaitkan dengan perilaku pergerakan masyarakat paling banyak adalah untuk berbelanja, hal ini sesuai dengan peruntukan kawasan bisnis simpur center.

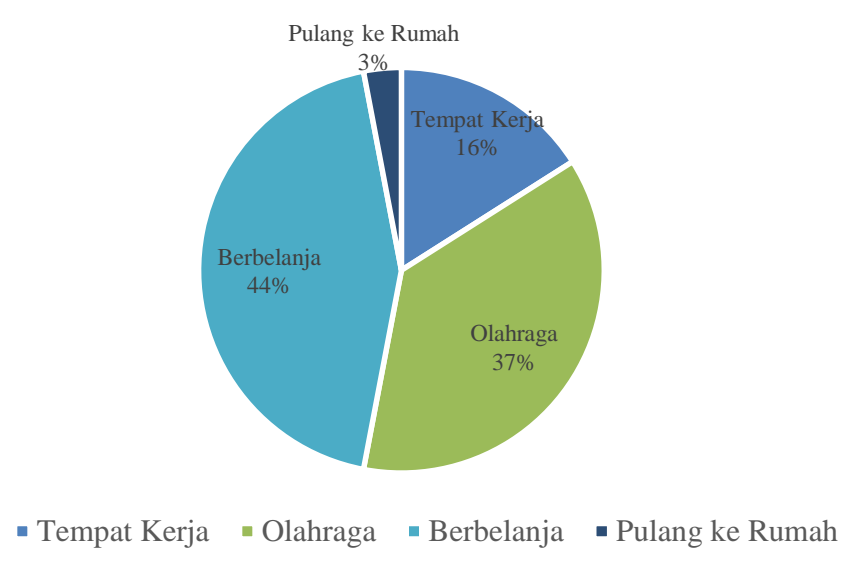

Gambar 3. Diagram Tujuan Pergerakan Pejalan Kaki di Kawasan Bisnis Simpur Center

Adapun fenomena di masyarakat perkotaan yang menggunakan jalur pejalan kaki sebagai prasarana olaharaga, seperti jogging bahkan bersepeda di jalur pejalan kaki karena tidak tersedia jalur khusus pesepeda. Hal ini juga bisa menjadi rekomendasi dalam penyediaan jalur pejalan kaki di perkotaan seperti di Kota Bandarlampung.

\section{Tingkat Walkability di Kawasan Bisnis Simpur Center dan Sekitar}

Secara umum walkability memperhitungkan kualitas jaringan jalur pejalan kaki (trotoar, jalur penyeberangan), konektivitas jaringan jalur pejalan kaki, keamanan serta kepadatan dan aksesibilitas. Pada penelitian ini skala penilaian dibagi kedalam tiga kelompok yaitu: (3) jalur pejalan kaki dapat diterima; (2) jalur pejalan kaki buruk; (1) jalur pejalan kaki dan lingkungan tidak layak untuk pejalan kaki. Dasar dari penilaian merupakan elaborasi dari kebijkan perencanaan jalur pejalan kaki di perkotaan dan parameter walkability. Berikut hasil penilaian menggunakan teknik survai walkthrough.

Tabel 2. Penilaian Walkability

\begin{tabular}{|l|c|}
\hline \multicolumn{1}{|c|}{ Parameter } & Skala Penilaian \\
\hline Konflik jalur pejalan kaki dengan moda transportasi lainnya & 2 \\
\hline Ketersediaan jalur pejalan kaki & 2 \\
\hline Ketersediaan penyeberangan & 3 \\
\hline Keselamatan penyeberangan & 1 \\
\hline Perilaku Pengendara Kendaraan bermotor & 1 \\
\hline Amenities (kelengkapan pendukung) & 2 \\
\hline Infrastruktur penunjang kelompok penyandang cacat & 1 \\
\hline Kendala/ hambatan & 2 \\
\hline Keamanan dari kejahatan & 2 \\
\hline
\end{tabular}

Sumber: Hasil Survai Walkthrough, 2020 
Pada Tabel 2 menjelaskan mengenai penilaian kondisi eksisting jalur pejalan kaki di kawasan bisnis simpur center. Proporsi penilaian paling banyak yaitu jalur pejalan kaki buruk \& jalur pejalan kaki dan lingkungan tidak layak untuk pejalan kaki.

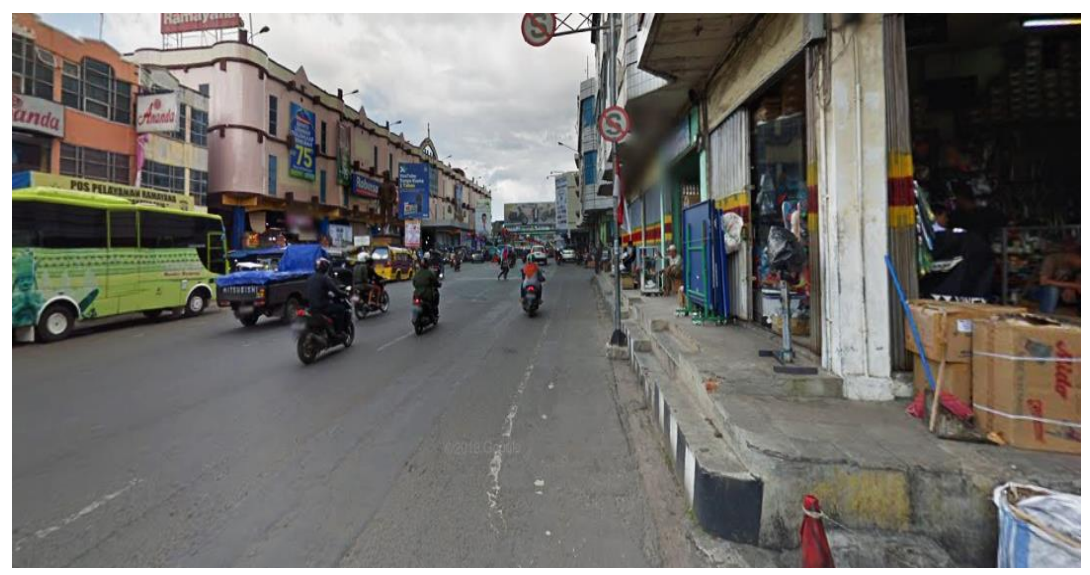

Gambar 4. Kondisi Eksisting Jalur Pejalan Kaki Kawasan Bisnis Simpur Center

Hasil penilaian dari survai walkthrough sesuai dengan kondisi sebenarnya jika dikomparasi dengan kebijakan perencanaan jalur pejalan kaki perkotaan untuk indikator perilaku pengendara tergolong tidak disiplin sehingga berpengaruh terhadap indikator keselamatan pejalan kaki saat menyebrang. Karena adanya konflik antar jalur pejalan kaki dengan moda lainnya seperti sepeda, sepeda motor dan mobil ini menyebabkan tingkat keamanan baik keamanaan berjalan maupun tindak kriminal menjadi sangat rendah. Infrastruktur penunjang kelompok pejalan kaki berkebutuhan khusus disepanjang jalan tidak ditemukan kemenerusannya, sehingga akan menimbulkan masalah. Kendala atau hambatan yang sering ditemukan pada jalur pejalan kaki adalah adanya kegiatan PKL dan parkir pada jalur pejalan kaki yang dapat merugikan pejalan kaki, karena travel time akan menjadi lebih panjang. Sehingga ini akan menjadi rekomendasi dalam merumuskan rencana penyediaan jalur pejalan kaki di kawasan bisnis sekitar jalur pejalan kaki.

\section{Rumusan Rekomendasi Penyediaan Jalur Pejalan Kaki yang Walkable di Kawasan Bisnis Simpur Center dan Sekitar}

Berdasarkan hasil analisa diketahui paling banyak pengguna jalur pejalan kaki digunakan untuk mendukung kegiatan belanja, sesuai dengan pola guna lahan yang tersedia. Jalur pejalan kaki tersedia dengan skala penilaian jalur pejalan kaki buruk, baik dari penyediaan fisik dan lingkungan sekitar. Hambatan samping yang ditemukan disepanjang jalur pejalan kaki seperti adanya pedagang kaki lima, on street parking dan angkot yang sering berhenti menunggu penumpang di sepanjang pinggir jalan Kawasan simpur center, mengakibatkan kemacetan dan menurunkan tingkat keamanan. Maka dari hasil survai dan anlisis, dapat dievaluasi perencanaan jalur pejalan kaki masih butuh banyak perbaikan sesuai dengan peraturan perencanaan jalur pejalan kaki di perkotaan dan kelengkapan fasilitas penunjang terutama bagi pejalan kaki disable atau berkebutuhan khusus dalam kondisi buruk. Jalur pejalan kaki secara keseluruhan tidak memenuhi syarat kemenerusan atau kontinyu, syarat ini menjadi penting untuk menciptakan jalur pejalan kaki yang walkable. 
JURNAL KACAPURI

JURNAL KEILMUAN TEKNIK SIPIL

Volume 3 Nomor 1 Edisi Juni 2020

\section{Kesimpulan}

\section{PENUTUP}

Dari hasil analisis diketahui kualitas walkability adalah jalur pejalan kaki buruk. Beberapa rekomendasi untuk evaluasi penyediaan jalur pejalan kaki dapat menjadi masukan agar jalur pejalan kaki dapat mendukung kegiatan belanja masyarakat Kota Bandarlampung.

\section{Saran dan Rekomendasi}

Penilaian kualitas walkability akan lebih baik dilakukan dengan menanyakan langsung kepada pejalan kaki dengan kuesioner sebagai pengguna dan wawancara kepada stakeholder selaku penyedia. Penilaian kualitas juga dapat dimodelkan untuk menyusun jalur pejalan kaki yang walkable tidak hanya pada kawasan bisnis tapi juga pada kawasan pemerintahan, pendidikan, ibadah dan lainnya.

\section{DAFTAR PUSTAKA}

ITDP. 2016. Non Motorized Transport. Jakarta: ITDP Indonesia.

Krambeck, Holly V. 2006. "The Global Walkability Index”. Thesis. Massachusetts Institute of Technology.

Leather, J., Herbert Fabian, Sudhir Gota, Alvin Mejia. 2011. Walkability and Pedestrian Facilities in Asian Cities State and Issues. Metro Manila: ADB Sustainable Development Working Paper Series.

Litman, T.A. 2014. Economic Value of Walkability. Victoria Transport Policy Institute.

Ministry for the Environment. 2006. Urban Design Toolkit. New Zealand.

Shirvani, H. 1985. The Urban Design Process. New York: Van Nostrand Reinhold. 